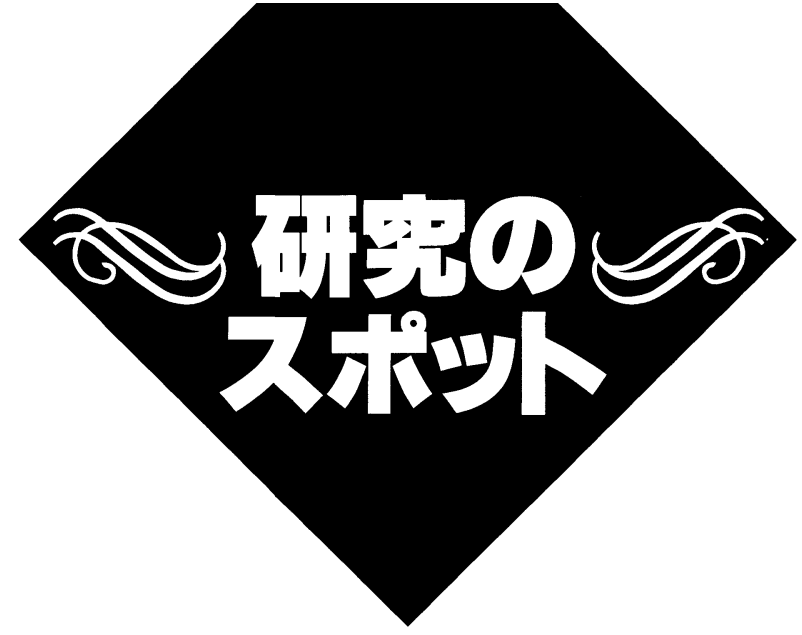

\title{
葉緑体のアスコルビン酸ペルオキシダーゼ合成 の巧みなメカニズム
}

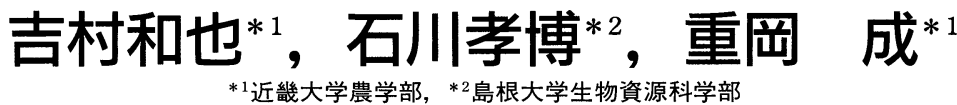

葉緑体は太陽エネルギーから化学エネルギーへの変換 の場であるとともに，植物細胞にとって主要な $\mathrm{O}_{2}$ 発生 源となっている，植物細胞内の $\mathrm{O}_{2}$ 濃度は $250 \mu \mathrm{M}$ 以上 であり, 動物細胞のミトコンドリア内の濃度 $\left(10^{-7} \sim 10^{-8}\right.$ M) と比べても非常に高い。このような状況下で, 光照射 により光化学系 I で生成した余剩電子の一部は, チラコ イド膜表面に局在するストロマ因子 (フラビン酵素のモ ノデヒドロアスコルビン酸レダクターゼが候補と考えら れている)を介して $\mathrm{O}_{2}$ を還元し, 活性酸素種の一つであ るスーパーオキシド $\left(\mathrm{O}_{2}{ }^{-}\right)$を生成する. $\mathrm{O}_{2}{ }^{-}$はさらに光 化学系 I 近傍に局在する $\mathrm{Cu} / \mathrm{Zn}$ 型スーパーオキシドデ イスムターゼ（SOD）により速やかに $\mathrm{H}_{2} \mathrm{O}_{2}$ に変換され る.この $\mathrm{H}_{2} \mathrm{O}_{2}$ 生成速度は約 $2.1 \mathrm{mM} \mathrm{s}^{-1}$ と見積もられて おり，低濃度 $(10 \mu \mathrm{M})$ の $\mathrm{H}_{2} \mathrm{O}_{2}$ は $\mathrm{CO}_{2}$ 固定能を $50 \%$ 失 活させるので，もし $\mathrm{H}_{2} \mathrm{O}_{2}$ が効率的に消去されなければ ただちに光合成は停止することになり，植物にとって死 活問題となる ${ }^{(1 \sim 3)}$.

光化学系 I で生成した活性酸素種は, Water-Water サイクルと呼ばれる図 1 に示す系で迅速に消去される. この系は光化学系 II で $\mathrm{H}_{2} \mathrm{O}$ の光酸化により生成した電 子が, 光化学系 $\mathrm{I} て ゙ \mathrm{O}_{2}$ を $\mathrm{H}_{2} \mathrm{O}$ に還元する循環的電子伝 達系で, 活性酸素種の消去だけでなく過剩の光量子エ
ネルギーを効率的に散逸させ，光合成による光酸化ス トレス回避のためにも機能している.この系はSOD, チラコイド膜結合型アスコルビン酸ペルオキシダーゼ (tAPX) およびフェレドキシンからなるチラコイド膜上 の還元系である.この系で処理しきれなかった活性酸素 は, さらにストロマに存在する SOD, ストロマ型アスコ ルビン酸ペルオキシダーゼ (sAPX)，モノデヒドロアス コルビン酸レダクターゼ，デヒドロアスコルビン酸レダ クターゼおよびグルタチオンレダクターゼの共役系によ り消去される(2).

最近, ホウレンソウから葉緑体型 APX アイソザイム (tAPX と sAPX)の分子特性と発現機構の解析が行なわ れた(3 6). その結果, 葉緑体型 APX アイソザイムはそ れぞれの遺伝子にコードされているのではなく，単一の 遺伝子 $(A p x I I)$ にコードされており，それらの成熟型 mRNA の発現は $3^{\prime}$ 下流領域の選択的スプライシング機 構により調節されていることが明らかになった。すなわ ち, 高等植物は葉緑体型 APXアイソザイムの局在化 を, それらの C 未端に疎水性のアンカーをつけるか否か で決定していたのである。植物細胞において，3末端エ クソンの選択的スプライシングによって一つのオルガネ ラに局在性の異なるアイソザイムを発現し，かつそれら 


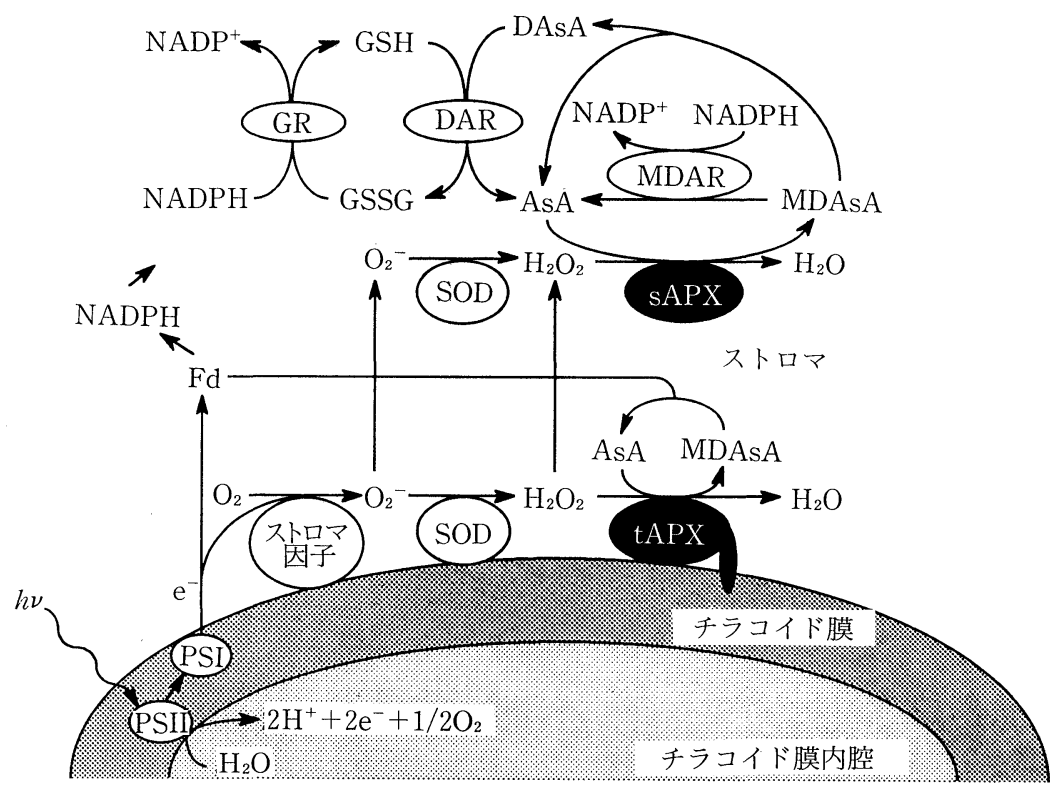

図 1 ・高等植物の葉緑体における Water-Water サイクル

AsA : アスコルビン酸, APX : アスコルビン酸ペルオキシダーゼ(sAPX : ストロマ型 APX, tAPX:チラコイド膜結合型 APX), DAsA：デヒドロ AsA, DAR：デヒドロ AsA レダクターゼ, GR：グルタチオンレダクターゼ, MDAsA：モノデヒドロ AsA，MDAR： モノデヒドロ AsA レダクターゼ, GSH : 還元型グルタチオン, GSSG：酸化型グルタチオン, PSI (II) : 光化学系 I(II)

の生理的役割が明らかになっている例は今までにほとん どない.

\section{葉緑体型 APX アイソザイムの不安定性}

APX は葉緑体以外にアイソザイムとして細胞質，ミ クロボディにも局在し，それぞれの分子特性も明らかに されている ${ }^{(1,7 \sim 9)}$. 最近では，ミトコンドリアやアポプラ ストにも APX 活性が存在するとの報告もある ${ }^{(10,11)}$. sAPX と tAPX の酵素学的性質は, 分子量の違いを除い て非常に類似していた。葉緑体型 APX アイソザイムの 特筆すべき性質として，アスコルビン酸 (AsA) 非存在下 での不安定性があげられる。これは APX の反応中間体 compound I の低濃度の $\mathrm{H}_{2} \mathrm{O}_{2}$ による失活に起因してい た。すなわち，葉緑体型 APX は特に $\mathrm{H}_{2} \mathrm{O}_{2}$ との感受性 が高く，充分な AsA $(20 \mu \mathrm{M}>)$ が存在しないとき， $\mu \mathrm{M}$ レベルの AsA の自動酸化で生成するnM レベルの $\mathrm{H}_{2} \mathrm{O}_{2}$ によって 60 秒程度で完全に活性を失う(1). 細胞質型 APX は葉緑体型 APX に較べ比較的安定ではあるが, 数 時間で失活する。最近，葉緑体に大腸菌由来のカタラー ゼ $(K a t E)$ を導入した形質転換夕バコを用いた実験か ら, 葉緑体型 APX の不安定性 (失活) が乾燥/強光の複合 ストレスによる初期段階での光・酸素毒障害の一因にな っていることが示唆された ${ }^{(12)}$. KatE 導入により獲得し
た酸素毒耐性は，失活した APX の代わりをカタラーゼ が補償することに起因していた。最近, 細胞質型 APX 変 異体の作製および結晶構造の解析により, APXの安定 性に関わるアミノ酸分子間の相互作用が明らかにされつ つある ${ }^{(13,14)}$. 葉緑体型 APX はその不安定性のため結晶 化が困難であるが，細胞質型 APX や他の植物ペルオキ シダーゼとの安定性の違いに関する分子レベルでの解析 が進行中である.

\section{選択的スプライシングによる葉緑体型 APX アイソザイムの生成}

最近, ホウレンソウの sAPX と tAPX の全長をコード する cDNA が得られた. 両アイソザイムの推定アミノ酸 配列から， sAPX (365アミノ酸残基)のC 末端の 1 つの

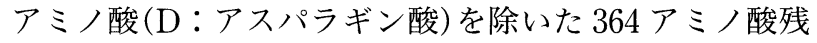
基(70アミノ酸残基の葉緑体移行シグナルを含む)は, tAPX (415 アミノ酸残基)の $\mathrm{N}$ 末端からの配列と完全に 一致していた。 tAPXのC 末端はsAPXよりさらに 50 アミノ酸残基長く，この領域は疎水性アミノ酸に富み, アンカーとしてチラコイド膜結合に関与していた ${ }^{(4)}$. 同 様の特徵は, ミクロボディ膜結合型 APX にも認められ た ${ }^{(8)}$.

ゲノム解析の結果, 図 2 に示すようにApxII は 13 個 のエクソンで構成されており，エクソン 1 から 11 には 


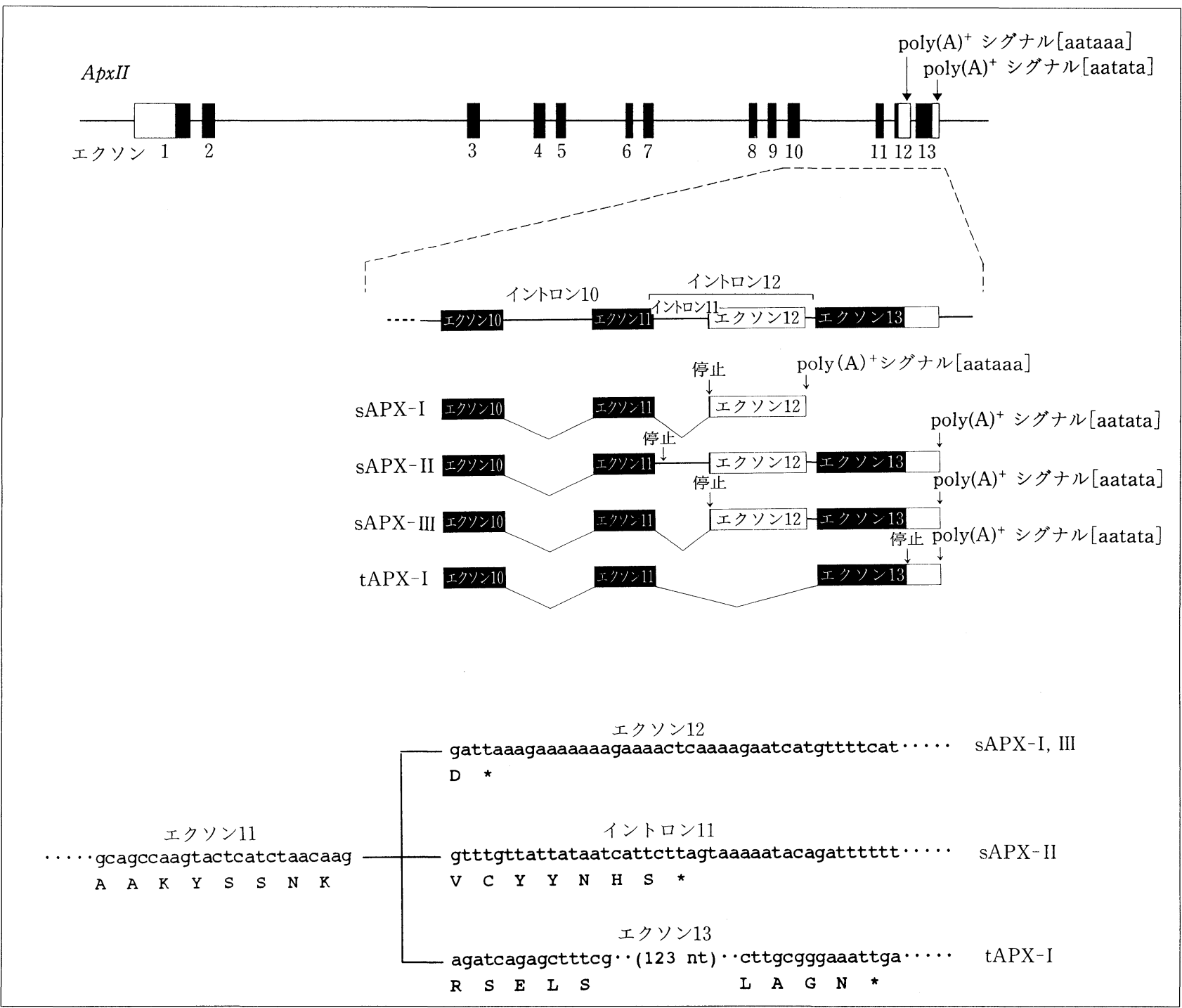

図 2 ・葉緑体型 APX アイソザイムの遺伝子 $(A p x I I)$ および成熟型 mRNA

ApxII は 13 個のエクソンで構成されている. エクソン 1 から 11 までは sAPX および tAPX のための共通領域，エクソン 12 および 13 に はそれぞれ sAPX のC 末端アミノ酸(D)およびtAPX のチラコイド膜結合領域がコードされている. それぞれのエクソンには終止コドン およびポリアデニレーションシグナルが含まれている．３３領域の選択的スプライシングの結果として，4種類の葉緑体型 APX の成熟型 mRNA が存在する.

sAPX と tAPX のための共通配列がコードされていた. エクソン 12 および 13 にはそれぞれ SAPX のC 末端ア ミノ酸 $(\mathrm{D})$ および tAPX のチラコイド膜結合領域がコー ドされていた。 また, それぞれのエクソンには終止コド ンおよび推定されるポリアデニレーションシグナルが 含まれていた。このことから, ホウレンソウ葉緑体型 APX アイソザイムの成熟型 mRNA は $3^{\prime}$ 末端エクソン の選択的スプライシングにより生成することが明らかに なった ${ }^{(5)}$. 一般に, 真核生物の遺伝子はエクソンとイン トロンで構成されており, 転写後の RNA プロセッシン グの過程におけるスプライシング（構成的スプライシン グ）により，前駆体 mRNA からイントロンが取り除か
れる.ところが，一部の前駆体 mRNA では多数のスプ ライシング部位が認識され, スプライシング様式の違い により複数の成熟型 mRNA が生成する。これは選択的 スプライシングと呼ばれ，一つの遺伝子から局在性や性 質の異なる複数のタンパク質を生成する非常に合理的か つ効率的な遺伝子発現調節機構である ${ }^{(15)}$.

当初, 筆者らは葉緑体型 APX アイソザイムは, 選択的 スプライシングによりそれぞれのアイソザイムをコード する成熟型 $m R N A$ が単純に一つずつ生成していると考 えていた.しかし，RT-PCRにより解析したところ，実 際には複雑なプロセッシングの過程を経た $3^{\prime}$ 側の構造 のみが異なる 4 種類の成熟型 mRNA の存在が確認され 
た(図 2) ${ }^{(6)}$.それらはすべてエクソン 1 から 11 を含んで いたが, その下流の構造の違い, すなわちイントロン 11 , エクソン 12 およびエクソン 13 の有無により， sAPXI , - II, -IIIおよび tAPX-I mRNA に分類された.エク ソン 12 および 13 にはそれぞれ SAPX のC末端アミノ 酸および tAPX の膜結合ドメインが存在しているため, sAPX-IおよびsAPX-III mRNA はsAPX タンパク 質, tAPX-I mRNA はtAPX タンパク質をコードして いることになる。一方， sAPX-II mRNA はイントロ ン 11 がスプライシングされておらず，イントロン 11 を コード領域とするため, sAPX - I および sAPX - III mRNA と比較してC末端側が 6 アミノ酸残基長い SAPX をコードしていることになる。このsAPX-II mRNA 由来の組換え体 APX は従来の sAPX と同じ酵 素学的性質を示した。また，すべてのタイプの成熟型 mRNA はポリゾーム上においても検出され，すべてタ ンパク質合成に関与していると考えられた ${ }^{(6)}$.

ホウレンソウ葉緑体型 APX と同じ遺伝子構造は, カ ボチャ葉緑体型 APXでも報告された ${ }^{(16)}$ 。また，筆者ら は夕バコおよび耐塩性植物アイスプラントにも，同様の 葉緑体型 APX 遺伝子および同じ種類の成熟型 mRNA の存在を確認した。一方，シロイヌナズナの葉緑体型 APX アイソザイムは別々の遺伝子にコードされている ことが示されている ${ }^{(17)}$. また, 筆者らは高等植物以外で も真核藻類の APX の分子特性を明らかにしている。そ の中で,クラミドモナス葉緑体には t APX は存在せず, sAPX のみが認められた。このことから, 葉緑体型 APX の選択的スプライシング機構は高等植物が進化過程にお いて獲得したものであると考えられるが，植物種により 発現機構が異なることも明らかである。これらの発現機 構の違いがそれぞれの植物のもつ活性酸素消去や環境適 応能に, どのような影響を与えているのか興味深い問題 である。

\section{葉緑体型 APX アイソザイム mRNA の 発現調節機構}

選択的スプライシングによって生成する 4 種類の成熟 型 mRNAの発現は, どのような調節を受けて, 最終的 に葉緑体での APX アイソザイムの存在量や比率に影 響を及ぼしているのであろうか. 定常状態における各 mRNA の発現比率を播種 4 週間後のホウレンソウ葉を 用いて検討したところ， SAPX-I，－II，一III および tAPX-I mRNA はそれぞれ $21: 5: 32: 42$ の割合で存 在していた ${ }^{(6)}$.しかし, sAPX-II mRNA は発現比率が 非常に少なく，最近筆者らが作製した抗ホウレンソウ
sAPX モノクローナル抗体を用いたイムノブロッティン グでも, sAPX-II mRNA 由来のタンパク質は検出で きなかったことから, SAPX-IIの生理的役割はきわめて 低いと考えられた. したがって, sAPX-II mRNAを除 いた tAPX と sAPX mRNAの総発現量の割合はほほ $1: 1$ となり, この事実は, ホウレンソウ葉緑体の両アイ ソザイムのタンパク質と活性レベルがほぼ等しい結果と 一致していた ${ }^{(6)}$.

次に, これらの mRNA 発現量と比率を種々の環境条 件下で検討した。葉緑体型 APX の総 mRNA 発現量は, 環境条件や組織の違いでは有意な影響を受けず，ほぼ 同じレベルで恒常的に発現しており, 細胞質型 APX mRNA で観察されるような顕著な変動はみられなかっ た。しかし, 一定量の葉緑体型 APX 総 mRNA の発現の 中で, sAPX-III と tAPX-I mRNA の発現比率は, 環境 条件や各組織のプラスチドの形態に合わせて変化してい た. ホウレンソウ黄化子葉を光照射 $\left(300 \mu \mathrm{E} \mathrm{m}^{-2} \mathrm{~s}^{-1}\right)$ す ると tAPX-I mRNA の発現比率が $32 \%$ か $42 \%$ に増 加し, sAPX-III mRNA は $40 \%$ から $32 \%$ に減少して いた。一方, 茎㧍よび根では tAPX-I mRNA は総発現 量の $5 \%$ に抑制され, sAPX-III mRNA は総発現量の およそ $75 \%$ を占めていた。しかし，いずれの場合も sAPX-I とsAPX-II mRNA の発現比率は常に一定で あった。

これまでの結果をまとめて, ホウレンソウ葉緑体型 APX の選択的スプライシングによる発現調節機構を図 3 に示した。 遺伝子の転写から成熟型 mRNAの生成に 至るまでのプロセッシングは, ポリアデニレーションシ グナルの認識と 3 末端のポリ $\mathrm{A}$ 形成およびその後に起 こるスプライシングからなる. 葉緑体型 APX アイソザ イムの選択的スプライシングによる発現には, これら のプロセスが深く関連している．３末端形成におい て, 動物では㛜密に規定されたポリアデニレーションシ グナル(AAUAAA)が必要であるが, 植物のポリアデニ レーションシグナルは動物ほど㛜密でなく AAUAAA に類似した様々なモチーフが同程度に認識されること が，タバコプロトプラストを用いた実験から示されてい る(18). ApxII のエクソン 12(AAUAAA) とエクソン 13(AAUAUA) に存在するポリアデニレーションシグナ ルの選択(比率はほぼ20：80である)にはこの認識の “寛容さ”が重要なのかもしれない.すなわち，2つのポ リアデニレーションシグナルの選択比率はそれぞれの配 列に依存するのではなく, それぞれのシグナルを含む周 辺領域の構造抢よび位置関係により決定していると考え られる。さらに, 前述のように環境条件や組織の違い 


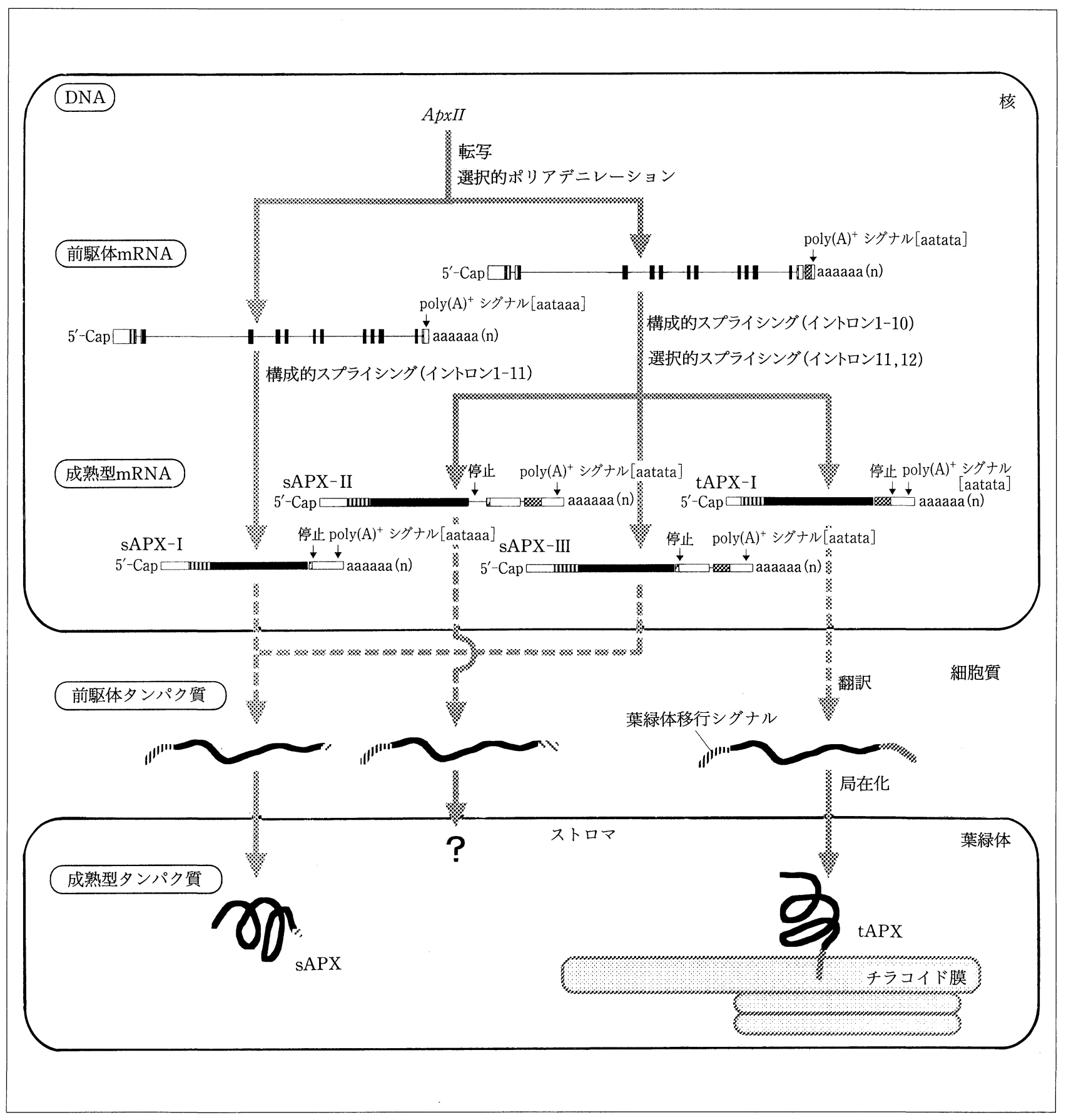

\section{図 3 - 葉緑体型 APX アイソザイムの生成}

ApxII から転写された前駆体 mRNA に対し, エクソン 12 もしくは 13 に存在するポリアデニレーションシグナルの選択が起こる. エクソ ン 12 のシグナルが選択された前駆体 mRNA は，イントロン 1 から 11 が構成的スプライシングにより除かれて成熟型の sAPX-I mRNA になる.一方，エクソン 13 のシグナルが選択された前駆体 mRNA は，イントロン 1 から 10 の構成的スプライシングおよびイントロン 11 もしくは 12 の選択的スプライシングが生じ，成熟型の sAPX-I, -IIもしくは tAPX-I mRNA になる. 各成熟型 mRNA はリボゾーム上で 翻訳され, 前駆体タンパク質が生成する。葉緑体に移行した後, sAPX-I および-III mRNA 由来のタンパク質( $\mathrm{sAPX)}$ はストロマに, tAPX-I mRNA 由来のタンパク質(tAPX) は C 未端の疎水領域をアンカーとしてチラコイド膜に局在する. sAPX-II mRNA 由来のタン パク質がストロマ中に存在しているかは不明である.

で，葉緑体型 APX の総 mRNA 発現量はほとんど変化 しなかったが，sAPX-III と tAPX-I mRNA の比率は変 化していた。したがって，sAPXおよびtAPXの総
mRNA の発現比率は，選択的ポリアデニレーションに より影響されるのではなく，これに続くイントロン 11 およびイントロン 12 の選択的スプライシングにより調 
節されていると考えられた.

高等植物の構成的スプライシングには，イントロン内 の AT 含量が高いことが必要であることが示されてい

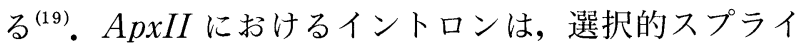
シングに関連するイントロン 11 および 12 を含めて AT 含量が高い.このことから, 葉緑体型 APX の選択的ス プライシングでは, 構成的スプライシングと選択的スプ ライシングに関連する因子の相互作用の必要性が考えら れる，高等植物ではスプライシング因子に関する情報は 少ないが，最近シロイヌナズナから植物遺伝子に特異的 で，選択的スプライシングにも関連するスプライシング 因子(atSRp30)が単離された ${ }^{(20)}$. 現在, 筆者らは葉緑体 型 APX の選択的スプライシング機構の調節に関与する シスートランス因子の同定を試みている.

\section{$*$}

以上，葉緑体型 APX アイソザイムの発現が選択的ス プライシング機構によって調節されていることを述べて きた。この機構により，高等植物は葉緑体のストロマお よびチラコイド膜に同じ機能をもった APX の供給を可 能にしている，植物細胞の活性酸素生成と消去系は，強 光・乾燥・低温などの環境ストレスと密接に関連してい る. 葉緑体における APX アイソザイムの役割の重要性 を考えると，選択的スプライシング機構による成熟型 mRNA の発現比率の調節は, これらの環境ストレス応 答に大きな影響を及ぼしていると思われる，最近，複合 的な環境ストレス而性植物の創製を目指して，活性酸素 消去関連の酵素を導入した形質転換植物の分子育種も盛 んに行なわれている ${ }^{(21,22)}$. 今後，環境ストレス応答およ び而性機構の解明のためには，活性酸素消去系の相互作 用の総合的な理解が必要と思われる. APX は今回紹介 した葉緑体以外に細胞質，ミクロボディにもアイソザイ ムが局在するＡPX アイソザイムが機能するためには 基質となるAsA の生合成, 輸送さらには再還元系の働 きも重要である.さらに，活性酸素種の寿命と反応性を 考慮すると，それらの生成部位付近すなわちミクロな局 在での消去システムの応答の解析もますます重要になっ てくる. 葉緑体型 APX アイソザイムの発現調節機構 は, 植物の巧みな環境適応への戦略の一端を, 我々に垣 間見させてくれている.

謝辞：本稿執筆の機会を与えていただきました東北大学大学院農 学研究科前忠彦教授に深謝いたします。

\section{文献}

1) K. Asada : "Oxidative Stress and the Molecular Biology of Antioxidant Defences”, ed. by J.G. Scandalios, Cold
Spring Harbor Laboratory Press, 1997, p.715.

2) K. Asada: Annu. Rev. Plant Physiol. Plant Mol. Biol., 50, 601 (1999).

3）重岡 成, 石川孝博, 武田 徹, 田茂井政宏：蛋白質 核酸 酵 素, 43, 634 (1998).

4) T. Ishikawa, K. Sakai, K. Yoshimura, T. Takeda \& S. Shigeoka: FEBS Lett., 384, 289 (1996).

5) T. Ishikawa, K. Yoshimura, M. Tamoi, T. Takeda \& S. Shigeoka : Biochem. J., 328, 795 (1997).

6) K. Yoshimura, Y. Yabuta, M. Tamoi, T. Ishikawa \& S. Shigeoka: Biochem. J., 338, 41 (1999).

7) T. Ishikawa, K. Sakai, T. Takeda \& S. Shigeoka : FEBS Lett., 367, 28 (1995).

8) T. Ishikawa, K. Yoshimura, K. Sakai, M. Tamoi, T. Takeda \& S. Shigeoka : Plant Cell Physiol., 39, 23 (1998).

9) K. Yoshimura, T. Ishikawa, Y. Nakamura, M. Tamoi, T. Takeda, T. Tada, K. Nishimura \& S. Shigeoka : Arch. Biochem. Biophys., 353, 55 (1998).

10) H. Vanacker, T.L.W. Carver \& C.H. Foyer: Plant Physiol., 117, 1103 (1998).

11) A. Jiménez, J.A. Hernández, G. Pastori, L.A. del Río \& F. Sevilla : Plant Physiol., 118, 1327 (1998).

12) T. Shikanai, T. Takeda, H. Yamauchi, S. Sano, K. Tomizawa, A. Yokota \& S. Shigeoka : FEBS Lett., 428, 47 (1998).

13) A.P. Hill, S. Modi, M.J. Sutcliffe, D.D. Turner, D.J. Gilfoyle, A.T. Smith, B.M. Tam \& E. Lloyd : Eur. J. Biochem., 248, 347 (1997).

14) D. Mandelman, F.P. Schwarz, H. Li \& T.L. Poulos : Protein Sci., 7, 2089 (1998).

15) M. Mckeown: Annu. Rev. Cell Biol., 8, 133 (1992).

16) S. Mano, K. Yamaguchi, M. Hayashi \& M. Nishimura : FEBS Lett., 413, 21 (1997).

17) H.M. Jespersen, I.V.H. Kjaersgard, L. Ostergaard \& K.G. Welinder : Biochem. J., 326, 305 (1997).

18) H.M. Rothnie, J. Reid \& T. Hohn : EMBO J., 13, 2200 (1994).

19) J.W.S. Brown \& C.G. Simpson: Annu. Rev. Plant Physiol. Plant Mol. Biol., 49, 77 (1998).

20) S. Lopato, M. Kalyna, S. Dorner, R. Kobayashi, A.R. Krainer \& A. Barta : Genes Dev., 13, 987 (1999).

21) L. Slooten, M.V. Montagu \& D. Inzé : “Transgenic Plant Research”, ed. by K. Lindsey, Harwood Academic Publishers, 1998, p. 241

22）重岡 成，宮川佳子，田茂井政宏：蛋白質 核酸 酵素，44, 2246 (1999). 